УДК 930.2(477):355.48(100)“1939/1945”:069.9

DOI: 10.33099/2707-1383-2020-38-4-29-44

Легасова Л.В., заступник генерального директора з наукової робот, Начіональний музей історії України у Другій світовій війні.

Меморіальний комплекс (м. Київ, Україна) ORCID https://orcid.org/0000-0002-4312-4914

Сімперович B.M., кандидат історичних наук, учений секретар, Національний музей історії Україниу Другій світовій війні.

Меморіальний комплекс (м. Київ, Украӥна)

ORCID https://orcid.org/0000-0001-7845-0667

\title{
ЕКСПОЗИТАРНА МОДЕЛЬ ІСТОРІЇ ДРУГОЇ СВІТОВОЇ ВІЙНИ: НАУКОВИЙ ДИСКУРС
}

У статті розглядаються особливості концептуальних схем, наративних та репрезентаційних сюжетів украӥнського досвіду найбільшого мілітарного конфлікту ХХ ст. В експозитарній моделі, яка розробляється та втілюється в науково-комунікативних практиках Національного музею історії Украӥни у Другій світовій війні. Меморіальний комплекс. Запропоновані конщептуальні та наращійно-репрезентаційні підходи до трактування українського виміру Другої світової війни можуть слугувати переконливим взірием і використовуватися як дієвий варіант потенційних музейно-експозичійних трансформацій.

Ключові слова: Друга світова війна, украӥнський вимір Другої світової війни, Національний музей історії Украӥни у Другій світовій війні. Меморіальний комплекс, експозитарна модель, концептуалізація, музейна нарація, музейна репрезентація.

Нині музеї, в експозиціях яких хоча б дотично репрезентується й наративується розлогий темарій Другої світової війни, стали «заручниками» своєрідної «патової» ситуації:як подавати події минулої війни, зважаючи на відсутність єдиної концептуальної її схеми (адже складно заперечити факт;попри те що іiі історія перебуває під постійним «прицілом» світової та вітчизняної історіографії, дискутується в політичних колах і не сходить зі шпальт ЗМІ, ми й надалі сперечаємося про те, як говорити про цей апокаліпсис XX ст.), строкатість колективної та історичної пам'яті, пере- важну «радянськість» їі фондово-джерельної бази. Не потрібно забувати й про те, що маємо діяти виключно в системі правових координат пакета «декомунізаційних» законів. Саме тому актуальним завданням для кожної музейної інституції залишається приведення експозитарного простору у відповідність до цих та інших викликів сучасності. Як у такій непростій ситуації діє найбільший військово-історичний музей нашої держави - Національний музей історії України у Другій світовій війні. Меморіальний комплекс (далі - Музей). Саме на прикладі його досвіду експозитарних 
нарацій, репрезентацій та науково-комунікативних ініціатив спробуємо поговорити, як знайти вихід із такого становища.

Теоретико-методологічні, концептуальні, історіософські, пам'яттєві та подієві складники історії Другої світової війни перебувають у фокусі багатьох дослідників. Поміж зарубіжних учених слід назватиП. Берка, А. Гаскелла, М. Гейстінгса, Дж. Леві, П. Нора, Г. Принса, Т. Снайдера, Є. Топольського та Дж. Шарпа [4; 22; 23; 33;37].У межах сучасної вітчизняної історіографії цими проблемами активно займаються В. Гриневич, С. Скельчик, О. Лисенко, I. Патриляк, А. Портнов, Я. Примаченко, О. Стяжкіната ін. $[6 ; 11 ; 17 ; 25 ; 29 ; 32 ; 35]$. Серед музеєзнавчих вислідів необхідно виокремити розвідки Н. Гамарник, А. Кузьменка, Л. Легасової, Р. Маньковської, Д. Пантьо, В. Фоміної, Н. Шевченко [3; $15 ; 16 ; 19 ; 24 ; 38]$. Але питання, яким бути музейному експозитарному відображенню тематичних сюжетів найбільшого мілітарного конфлікту XX ст.,залишається відкритим.

У зв'язку з цим пропонована стаття, грунтуючись на концептуальних схемах i науково-експозиційних практиках, спродукованих Музеєм, має на меті показати якою повинна бути / стати експозитарна модель українського вектора Другої світової війни. Відповідно до мети визначено такі завдання:

- визначити особливості адаптування історіографічної ситуації та потреби маркування іiї концептуально-теоретичних орієнтирів до загальної концептуалізації експозитарного взірця;

- охарактеризувати рубіжні складники музейної нарації тематичних граней воєнної доби;

- показати основи репрезентаційного темарію і деталізувати візуалізаційні сюжети головної війни XX ст.
Тепер Музей є не лише інститутом духовної та соціальної пам'яті, а й своєрідним сакральним простором, місцем, де зберігаються суспільні та історичні цінності. Процес його брендування в руслі декомунізації та інноваційного теоретизування й категоріалізації історії Другої світової війни завершився оновленим найменуванням (2015 р.),а експозитарні площі, базовані на здобутках історіографії, потужному джерельно-фондовому наративі й сучасних досягненнях комеморативно-пам'яттєвих стратагем,уже давно перетворилися на «місце пам'яті» про найбільший збройний конфлікт XX ст. Варто також наголосити, що темарійний вимір наявних експозиційних локацій, як візуальних репрезентацій воєнного минулого, постійно доповнюється, коригується й перебуває у вирі викликів реекспозиційно-модернізаційних трансформацій. Саме тому в 2017 р. команда музейників і науковців узялася до написання Наукової концепції нової експозиції Національного музею історії України у Другій світовій війні. Меморіальний комплекс та складання тематичної структури, утілила апробаційні виставкові проекти, ініціювала проведення низки експертних зустрічей і обговорень. Зрештою, завдання реекспозиції визначаються й рівнем сучасного розвитку музейних технологій та дизайну, новітніх інформаційних ресурсів, модерними досягненнями мультимедіа.

Сталий концепт експозитарної моделі історії доби воєнного лихоліття залежить виключно від особливостей історіографічної ситуації, теоретичних постулатів науковців та рівня дієвого втілення цих напрацювань у музейну практику. Однак концептуалізація історії України у Другій світовій війні є надзвичайно складним, тривалим у вирішенні й багатоаспектним завданням сучасного вітчизняного історієписання. Реалізувати ці виклики надзвичайно складно, адже 
воєнний темарій упродовж цілого півстоліття радше був «безпрограшною картою в пасьянсі військово-ідеологічного протистояння двох світових світоглядно-політичних систем, ніж сферою об'єктивного наукового дослідження» [31, с. 12].

Радянська історіографія, культивуючи офіціоз-концепцію «Великої Вітчизняної війни радянського народу», перетворилася на своєрідну «фабрику» гіперболізації ролі СРСР, перекручення / спотворювання історичних фактів, створення та культивування відвертих міфів і кліше, некритичної героїзації та романтизації, табуювання «незручних» проблем. Лише після проголошення незалежності України вітчизняні дослідники почали активно руйнувати радянські стереотипи, позбуватися марксистських таросієцентричних упереджень, відмовлятися від заідеологізованих і глорифікованих тем. У фокусі уваги починають з'являтися проблеми антропології, історії повсякдення, соціальної та усної історії тощо. Водночас історіографія проблеми й надалі залишається своєрідним полігоном, а подекуди й джерелом політичних спекуляцій та соціальних містифікацій. Нині, за влучним висловом Я. Калакури, вона «перебуває на крутому переломі, зумовленому трансформацією українського суспільства від радянського тоталітаризму до демократії та пріоритету людських цінностей, який супроводжується поверненням історичній науці її природних функцій» [12, с. 23]. Разом 3 тим, як слушно зазначають К. Кондратюк та О. Сухий: «Для досліджень останніх років характерні розкутість думок і суджень, неупередженість, оригінальність наукових підходів, розширення дослідницької тематики» $[14$, с. 117$]$. Саме тому сучасна концептуальна модель історії України у Другій світовій війні базується на своєрідному «переплетінні / міксуванні» складників «старого» (модифікованого й реконстру- йованого радянського) та «нового» (національного) історіографічних дискурсів. На жаль, «навіть сьогодні в масовій свідомості історія Другої світової війни в Україні залишається сумішшю об'єктивних знань та історичних міфів» [26, с. 6-7].

Зводячи ці умовно конкуруючі історіографічні наративи до спільного знаменника, варто констатувати, що все-таки вітчизняним науковцям вдалося розпочати своєрідний «історіографічний поворот», сутність якого визначили такі позиції, як деполітизація, деміфологізація, деромантизація й деглорифікація війни, концептуальне осмислення іiї в контексті подій від осені 1939 р. до осені 1945 р. та критика радянського режиму. А методологічною основою нового погляду на історію Другої світової війни став «україноцентризм у його широкому розумінні: суто етатистський підхід поступався місцем антропологічному виміру воєнної доби, коли у фокус наукового пошуку переміщувалося україсське суспільство та різні його соціальні, етнічні, конфесійні, політичні, маргінальні групи» $[17$, с. 7]. Попри реалізацію цього «повороту» й імплементування сучасного методологічного інструментарію, подолати «розлам» вітчизняного історієписання Другої світової війни так і не вдалося. Саме тому викристалізовуються цілком логічні запитання: який вихід із цієї «патової» історіографічної ситуації? Як сформувати цілісну наукову концепцію історії України у Другій світовій війні? Як поєднати несумісні історичні міфи, продуковані двома історіографічними наративами й, головне, інтегрувати їх в логічну експозитарну розповідь?

Виходом із цього становища,своєрідною відповіддю має стати збалансований, «компаративний» підхід, що має синтезувати ці дві історіографічні версії українського виміру Другої світової війни. Він має ба- 
зуватися на принциповій, кардинальній де міфологізації воєнної історії, як одного, так й іншого історіографічного напряму. Ці пам'яттєві та історіографічні суперечки мають фарватеризуватися насамперед у спроби зрозуміти, дослідити й репрезентувати глибинні мотиви вчинків учасників і сучасників найбільшого мілітарного конфлікту XX ст. Насамперед наукові зусилля необхідно скерувати на інтерпретування історичних фактів і людських вчинків із висоти сучасності, показ глибинної сутності тих подій, а не їхніх політичних чи ідеологічних мотивів. Тому підтримуємо думку В. Гриневича, що найбільш придатною для України моделлю історичної пам'яті, а водночас й історіографічного дискурсу $є$ комбінація східно- та західноєвропейських з однозначним відкиданням пострадянської (яку нині культивують у Росії та Білорусі), адже від східноєвропейської моделі вже «запозичено» «бінарне засудження сталінського і гітлерівського тоталітаризмів та збереження культурного цивілізованого націоналізму, а ось від західноєвропейської моделі іще необхідно «взяти» концепцію гуманізму, покаяння, пошуку взаємного порозуміння між колишніми ворогами і союзниками, віддання шани всім загиблим і засудження героїзації війни як такої» [5, с. 125]. Невипадково нині потрібне «кардинальне переосмислення всього наративу війни. Концепція рівної відповідальності двох тоталітарних режимів має бути врівноважена покаянням за злочини, що їх вчинили українці, які воювали на боці цих режимів, а також у лавах третьої сили — УПА» [6, с. 64]. Отже, в умовах співіснування цих концептуальних підходів єдиним завданням має стати «вироблення прийнятних для антагонізованих частин суспільства проектів нормалізації рецепцій спільного минулого, позбавлених пафосної риторики й ментальних стереотипів» [30,с. 84]. Слід також погодитися 3 Л. Нагорною, що «не менш важливим завданням для вітчизняних істориків є вироблення реалістичного підходу до оцінки радянського періоду в історії України» [21, с. 189-190]. Не ставлячи за мету детально розглянути всі ключові досягнення та проблеми двох історіографічних дискурсів про історію України в Другій світовій війні, стисло виокремимо лише ті, які потребують особливої уваги.

Першочерговим завданням модерного історіографічного наративу $є$ апробація сучасних методологічних орієнтирів та чітке внормування дефінітивних конструктів. О. Лисенко з цього приводу зауважує: «Разом із ідеологізованою субординацією подій з радянської історіографії в сучасну перекочували ідеологеми комуністичної доби. Ця проблема могла б залишитися в суто схоластичній чи лінгвістичній площині, якби не родова властивість продукованих партійними ідеологами вокабулярій вступати в конфронтацію з усім, чого вони торкаються» [9, с. 42-43]. Нині насамперед «війна дефініцій» точиться навколо таких термінів і понять як, наприклад, «Велика Вітчизняна війна» - «Друга світова війна», «імперське возз'єднання» / «приєднання» — «анексія» / «окупація», «визволення / звільнення» — «вигнання», продовжують побутувати такі ідеологічно «скомпрометовані» дефініційні конструкти як «народне господарство», «німецько-фашистських окупаційний режим», «тимчасово окупована територія», «Велика Перемога», «всенародна боротьба» тощо. Концептуалізація історії Другої світової війни в Україні неможлива також без «прив'язки їі до Першої світової війни, міжвоєнного періоду, «холодної війни» і сучасних геополітичних потрясінь у світі», без імплементації вітчизняною історіографією проблеми тези про те, що «Друга світова війна стала логічним продовженням Першої світової війни, котра 
не розв'язала (а в багатьох випадках лише ускладнила) суперечки між основними імперіями та їхніми союзниками», без аналізу «імперських і великодержавних проектів усіх світових потуг (від планів збереження колоніальних імперій, до будівництва нових імперій в ідеологічній обгортці «життєвого простору», «захисту Азії від європейців» або «світової революції»)» [25, c. 172-173]. Характеризуючи весь концептуально-історіографічний комплекс у цій тематичній ніші, варто також нагадати, що й нині історієписання проблеми тяжіє скоріше до висвітлення макропроцесів, аніж мікропроцесів воєнного буття. У новітньому історіографічному процесі не перестають домінувати відносно широкі в хронологічному, територіальному та змістовному плані теми, військово-політична та економічна історія, окремі аспекти релігійного та культурно-освітнього життя. Водночас воєнна антропологія, соціальна й повсякденна історія фактично залишаються на маргінесах наукових студій, хоча і $€$ «найбільш багатообіцяючими 3 пізнавальної точки зору» [18, с. 156].

Висновуючи сучасний вітчизняний icторіографічний дискурс,можемо констатувати, що українська історіографія докорінно переоцінила витокові тенденції Другої світової та початковий етап німецько-радянської війн. Набули поширення наукові студії, в яких порушено проблеми підокупаційних повсякденних практик. Дослідники стали приділяти багато уваги антинацистському руху Опору, особливостям боротьби за незалежну Українську державу. Зріс інтерес до геноцидних і депортаційних акцій тоталітарних режимів, були значно трансформовані уявлення про роль, місце і характер Голокосту на теренах України, доволі інтенсивно студіюються суто «баталістичні» сюжети. Однак єдиного комплексного концепту не існує.
Вироблена сучасною вітчизняною історіографією концептуальна парадигма минулої війни не $є$ монолітною і позначена строкатістю методологічних підходів, дефініційних і фактуально-подієвих «різночитань». Невирішеним завданням сучасного історієписання є питання історичного синтезу, тобто створення повноцінної, самодостатньої історії України у Другій світовій війні.

Для музейного експозиційного мистецтва й сучасних технологій експозитарного трансформування надзвичайно актуальними є вибудуваний історіографічний концепт та умовна концептуальна модель, адже «історіографічні модулі - це концептуальні конструкції, що визначають основні віхи національно-державницької історії» [13, с. 490]. Уже було зазначено, що концептуалізація музейної репрезентації історії Другої світової війни ускладнюється багатоваріативністю історіографічних візій проблеми. У такій непростій ситуації необхідно переглянути підходи до іiі трактування, «виробити» власну позицію, не чекаючи, доки вітчизняна історична наука остаточно розставить усі крапки над «і».

Ревізіонуючи історіографічний дискурс, можна солідаризуватися з думкою О. Сухого про те, що для сучасного історієписання найбільш плідним має бути системний конвергентний підхід, який передбачає симбіоз різнобічних впливів на генезу державотворення [36, с. 26]. Саме тому, витворюючи власну теоретичну візію історії України у Другій світовій війні, Музей (зрештою, як i будь-яка інша музейна інституція, яка експозиціонує той чи інший воєнний темарій) має стати поєднувачем різновекторних елементів відтворення наративів різного світоглядного спрямування, уможливлюючи порівняння різних підходів до історії Другої світової війни. У цьому плані надзвичайно актуальним видається полідисциплінарний підхід, який репрезентує на менталь- 
них рівнях дослідження мікро- та макроiсторії [34, с. 5].Тут є сенс прислухатися до думки німецького історика Ф. Пінгеля, який зазначив: «Українська історіографія має сформувати - по суті, вперше, - національну історію. Під цим маю на увазі: історіографію, що є вільною від зовнішнього політичного втручання; історіографію, що не була би просто антирадянською або ж антиросійською, що не зосереджувалася б на віктимізації або ж приховуванні, але пояснювала б, які можливості існували для людей (від співпраці до колаборації, від опору до пристосування); історіографію, що зображала б як злочинців, так і жертв, і свідків, і що залишала б місце для «суб'єктивних» особистих досвідів, а також для «об'єктивних» результатів історичного дослідження» [27, с. 223].У цьому ракурсі варто солідаризуватися й із твердженням I. Патриляка: «Необхідно позбавитися уявлень про нашу участь у війні на стороні «сил добра». Антигітлерівська коаліція не складалася 3 «ангелів», а, тим більше, на таку роль не підходив сталінський СРСР. Те, що волею долі більшість українців опинилися в лавах Червоної армії, котра між 1941-1945 рр. воювала з вермахтом, не надає нам якогось особливого статусу в світі. Слід визнати, що наші предки у своїй абсолютній більшості (як і в багатьох попередніх війнах) віддавали життя та здоров'я за імперіалістичні інтереси Росії (Німеччини, Угорщини, Румунії, Польщі, Британії чи США). Ми не повинні ні героїзувати, ні демонізувати українців-червоноармійців, а ставитися до них 3 такою ж стриманою нейтральністю, як українська історіографія ставиться до українців у російській армії часів Першої світової війни» [25, с. 174].

Експозиційне образотворення історії України у Другій світовій війні, базуючись на здобутках історіографічних дискурсів, має враховувати насамперед антрополо- гічний, а потім подієвий виміри воєнного доби. Звичайно, з одного боку, необхідно у хронологічній послідовності викласти фактаж: коли й що відбувалося, хто де був і що робив, але з іншого - слід показати духовні зміни, внутрішні трансформації індивіда в умовах екстримального буття. Тут надзвичайно важливо репрезентувати історії звичайних, типових людей. Очільників тоталітарних режимів, колишніх партійних, державних чи громадських функціонерів потрібно показувати не лише як суб'єктів історії, а передусім як інструментів зла, як перешкоди на шляху соціуму до змін. Саме так, змальовуючи історії «знизу» й відкидаючи «ідеологічний верх» як рудимент суспільства, як тягар, можна вибудувати ідею, яка його об'єднуватиме. Потрібно відмовитися від ідеалізації тієї чи іншої сторони конфлікту, її діяльності.

Адаптування наукового дискурсу воєнної історії до комунікативно-наративних музейних практик потребує зрівноваженого образу учасника, героя та жертви збройного конфлікту; об'єктивації історичного знання - однієї з основних запорук створення стійкої, всебічної репрезентаційної системи історії України у Другій світовій війні в експозитарному просторі. Вибудуваний на основі різних історіографічних моделей пояснювальний модус воєнних подій має охоплювати насамперед пріоритет простору, а не пріоритет часу. Щоб позбутися всіх вад історіографії проблеми необхідно «відійти від принципу «націоналізуючої» моделі й увести вітчизняну історію у рамки часо-просторової або територіальної парадигми» [20, с. 189]. Репрезентуючи історію Другої світової війни, необхідно віднайти консенсус між національними й інтернаціональними іiі складниками, гармонізувати iii магістральні напрямні. Домінуючої інтерпретації воєнних подій потребує такий темарій: бойові дії в 1939-1945 pp., соці- 
огуманітарні складники війни та український визвольний рух і радянський рух Опору. Безумовно вагомим складником концептуального бачення історії України у Другій світовій війні має стати «українське питання» в період Першої світової війни та міжвоєння. Окремої уваги заслуговує Українська революція 1917-1921 рр. як вагома предтеча Других визвольних змагань. Характеризуючи військові потуги на теренах України, необхідно відійти від надміру спрощеного трактування цих подій у межах умовних конструктів «наші чужі», розглядати цей процес не лише під ракурсом «оборонних операцій Червоної армії на українській території» чи «визволення / звільнення / вигнання (від) нацистів України», а й у контексті загальної воєнної ситуації на Східному фронті. Надзвичайно важливим є соціогуманітарний аспект ії виміру, адже й донині не маємо повноцінного наукового пояснення, чим була українська спільнота напередодні, під час і після війни. У цьому контексті необхідно реконструювати процес довоєнної денаціоналізації та десоціалізації, суспільні відносини до рівня особи, особливості формування квазігромадських структур «радянського народу», соціальну організацію населення в умовах війни, «постокупаційний синдром» підокупаційного соціуму, вплив «відбудовних процесів» на життя, побут і повсякдення суспільства тощо. Комплексного бачення потребує проблема нацистського окупаційного режиму в Україні та сприймання його українцями. Необхідно відверто вести розмову про різноманітні «стратегії виживання»: більшість українців боролися за безпечнебуття, а не були причетні до колаборації чи спротиву. Як зауважив відомий німецький історик Д. Поль, «історія окупованих суспільств містить усі 3 цих аспектів - насилля, колаборацію, спротив і виживання» [28, с. 33]. Цю думку розвинув Я. Грицак, справедливо зазначивши: «Роздільна лінія між виною і невинністю, колаборацією і спротивом нерідко була тонка й ледь помітна. Прагнення виживати змушувало людей прибирати різні ролі» [7, с. 86-87]. Відвертого обговорення потребують складні з погляду моралі сторінки / явища Другої світової війни в Україні, зокрема питання Голокосту, геноцидних і депортаційних акцій тоталітарних режимів, польсько-українського протистояння, військових злочинів ворогуючих сторін, колізій навколо випадків девіаціїв Червоній армії й у лавах радянських партизанів, УПА та ін. Наративуючи український визвольний рух, необхідно акцентувати його державотворчий контент, спрямованість не лише проти Німеччини, Польщі або СРСР, а й на «реалізацію права українського народу на самовизначення» [25, с. 175]. Експозитарна ретрансляція подій Другої світової була б неповною без теми повоєнного буття в Україні. Історіографічно засвоєні особливості післявоєнного статусу, відбудовних робіт і реевакуації, голоду, другої «радянізації», «міжнародної суб'єктності» УРСР, реституції культурно-історичних цінностей, вивезених з українських теренів, мають перебувати в об'єктиві музейних репрезентацій та нарацій. Ті теми, які складно, а подекуди, через брак експозитарного матеріалу, й неможливо показати, мають ретранслюватись у виставковому, дискусійному та мультимедійному простоpax Музею. Те саме твердження справедливе й для інших музейних інституцій, які ретранслюють історію Другої світової війни та акцентують ії український вимір. Цілком свідомі, що запропонований концепт проблеми постійно потребуватиме ментальних конвенцій (роз'яснень, домовленостей та уточнень).

Розроблюючи нову експозицію, необхідно послуговуватися україноцентричним, 
історико-антропологічним принципами, принципами автентичності та музеальності (акцентування експонатури, що рельєфно передає біограми пересічних учасників та сучасників воєнного лихоліття), принципом історичної реконструкції (використання показу не тільки самих предметів, а й середовища, в якому вони побутували, атрактивація експозиції елементами театралізації та художньої символіки). Зрештою, музейно-експозитарний простір має бути конструкційно-симуляційним чи нараційно-реконструкційним, i, головне, критичним. Окрім того, реконструюючи складні сторінки історії Другої світової війни у музеальному вимірі, необхідно враховувати теоретико-методологічний інструментарій як академічної (конвенційної), так і неконвенційної (публічної, популярної) історії.«Якщо йдеться про академічну (конвенційну) історію, - зазначає Е. Доманська, - то такими методологічними правилами $\epsilon$, зокрема, культ факту, вимоги об'єктивності, принцип причинності, а також прагнення істини» [8, с. 95]. Водночас необхідно використовувати й методологічні підвалини історії неконвенційної, «історії, що шанує суб'єктивізм, у наративі ламає причинно-наслідковий порядок, із підозрою ставиться до поняття істини, експериментує зі способами представлення та використовує різні засоби передавання інформації, серед яких писані тексти є лише одним із можливих варіантів. Ця історія позитивно ставиться до емоцій, емпатії та щирості, що використовуються не тільки як методологічні засоби, але також сигналізують локацію автора в наративі, який часто розглядає історієписання як форму боротьби з різними формами утиску. Характерним також $є$ те, що її творці мають схильність до теоретизування і часто поєднують досконалий дослідницький вишкіл 3 дуже доброю озна- йомленістю з теорією та методологією. До того ж, якщо у випадку академічної історії конвенції пов'язані з посиланням на вимоги науковості в її традиційному розумінні, то у неконвенційній історії змінюється тип визнаних конвенцій, а самі вони часто окреслюються як цінності» [8, с. 96].У цьому сенсі набувають широкого значення усна історія, «візуальні студії, історія повсякденностій, зрештою, перформативна історія.

Під час побудови експозиції слід мати на увазі, що вона не повинна виконувати функції монографії або підручника. Це швидше своєрідний експозитарний наратив, який спирається на музейний предмет-оригінал і прагне до максимальної лаконічності допоміжного матеріалу. Потрібно зразу ж відкинути безнадійну спробу показати все, що стосується Другої світової війни загалом або окремої її теми. При висвітленні перипетій вітчизняної воєнної минувшини необхідно йти від загального до часткового, від лінійної описовості подій до родинної чи індивідуальної історії, виходячи з конкретних завдань і можливостей. Експозиційний простір повинен «занурювати» в атмосферу воєнного часу, передавати його внутрішню напругу й екзистенційність, проте не пригнічувати, а спонукати до переживання катарсису й дарувати надію. Завдання полягає ще й у тому, щоб відчувався тісний зв'язок між історією та сучасністю. Це передбачає хід від традиційної предметної експозиції до інформаційно-експозиційного музейного комплексу.

Проектуючи експозитарний простірі створюючи стійкий візуальний образ вітчизняної воєнної минувшини та місця в ній Людини, необхідно віддати належне й мистецько-зображальній моделі дійсності, адже «тільки художньо-образна побудова музейної експозиції відповідає складності, багатогранності, естетичному 
розмаїттю самого життя і дозволяє передати життедіяльність у іï ситуаційному розгортанні» [2, с. 67]. Проте слід пам'ятати, що «абсолютно об'єктивне або ідентичне відтворення історичної минувшини музейними засобами неможливе, бо оригінальні матеріальні пам'ятки із фондових зібрань зберігають тотожність собі, тобто автентичність свідчення тільки у контексті власної доби, надалі ж вони виступають матеріалом для формування наших уявлень про цю добу», а отже, «музейна експозиція будується не на зовнішній правдоподібності, а на авторському переосмисленні інформаційного потенціалу пам'яток і його сучасній інтерпретації» [2, с. 66]. Успішне створення експозиції також залежить від вдалого синтезування наукового й художнього проектування та збалансованого вибору музейних методів. Важливим складником реалізації методичних засад мають стати інтерактивні заходи й цифрові технології. Предметно-мультимедійні інсталяції, сучасна медіаінтерпретація, аудіовізуальні й світлотехнічні рішення значно розширюють можливості реконструкції та ре транслювання воєнної історії. Загалом цифровізація допомагає ефективно «боротися» 3 казенністю й формальністю музейних репрезентаційних практик.

Актуалізація джерельного контенту має відбуватися постійно, завдяки проведенню різнопланових дослідницько-пошукових експедицій та новим надходженням. Важливо зазначити, що в трансформований експозитарний простір повинні імплементуватися як джерела «радянського» й «німецького» походження, так і джерела 3 історії українського визвольного руху. Надзвичайно активно слід використовувати епістолярії та щоденникові записи учасників і сучасників Другої світової війни. У цьому контексті варто погодитися з О. Єгрешієм, що «жоден офіційний доку- мент, 3 якою б акуратністю і старанністю він не складався, не відтворить справжній переживань, настроїв, оригінальних оцінок, сумнівів чи вагань, як це демонструють матеріали епістолярного жанру. Саме у конфіденційних документах люди фіксують свої рішення, незгоду, а іноді й потаємні думки» [10, с. 21]. Для «експозиційного прочитання» названої автентики потрібно застосовувати відповідні критичні підходи. Саме тому актуалізований удокументований наратив має пройти перевірку на історичну цінність за такими критеріями:

- автентичність джерела - справжність тексту, як реального свідчення чи підробки викладеної в ньому історичної інформації;

- вірогідність джерела - ступінь відповідності його свідчень реальним історичним фактам, які в них описані;

- повнота джерела - рівень відбиття в тексті суттєвих сторін історичних фактів, подій та явищ;

— інформаційна новизна - наявність нової інформації, відсутньої в актуалізованій джерельній базі;

- репрезентативність - здатність джерела (чи всієї джерельної бази з визначеної теми) правильно відображати історичні факти загалом [1, с. 112-113].

Отже, за умови ефективного використання та втілення модерних засад вибудуваної концептуалізації, нараційних та репрезентаційних підходів і схем (зокрема, й науково-експозиційних ініціатив Музею) вітчизняна експозитарна модель історії Другої світової війни має трансформуватися у провідника, грамотного інтерпретатора нового осягнення різних іiї геополітичних, баталістичних, суспільно-політичних, соціокультурних, пам'яттєвих і комеморативних реалій, перейти від висвітлення історії Події до розгляду історії Людини, ретранслювати превалювання антропо- 
логічного матеріалу над загальноісторичним,реконструювати взамозалежність історичного змісту й контекстів довоєнного, воєнного та повоєнного періодів історії України і доль конкретних людей - переважно звичайних учасників тих історичних подій, досягти максимально можливої інформаційної насиченості інновативних експозицій, здатних задовольнити найрізноманітніші запити музейних відвідувачів. Унаслідок реалізації такої моделі як Музей, так і будь-яка музейна інституція, яка наративує події найзначнішого загальносвітового соціального катаклізму XX ст. (звичайно, в масштабах своїх географічно-просторових локацій) має стати багатофункціональним просвітницько-комунікативним і науково-дослідницьким центром, інтегратором наукової, освітньо-патріотичної діяльності з архівуванням, збереженням та репрезентуванням історії Другої світової війни, унікальною суспільною інституційною одиницею, покликаною служити місцем і простором культурної та наукової комунікації і взаємодії, інформаційного та ціннісного обміну між різними соціальними групами, поколіннями, професійними, віковими, територіальними та іншими спільнотами. Звісно, запропоновані варіанти потенційних експозитарних трансформацій, а також похідні від них прогнозовані результати є робочими. Дослідження та втілення практичних науково-експозиційних ініціатив триватиме й, безперечно, вони будуть уточнюватися, розширюватися й змінюватися.

\section{СПИСОК ВИКОРИСТАНИХ ДЖЕРЕЛІ ЛІТЕРАТУРИ}

1. Богдашина О.М. Джерелознавство історії України: питання теорії, методики, історії / O.М. Богдашина. - Х.: Сага, 2009. - 214 с.

2. Велика Л.П. Музейне експозиційне мистецтво: монографія / Л.П. Велика. - Х.: ХДАК, 2000. - $160 \mathrm{c}$.

3. Гамарник Н. Виставки-апробації в Національному музеї історії України у Другій світовій війні як виклик майбутній експозиції / Н. Гамарник // Військово-історичний меридіан. Електронний науковий фаховий журнал. - Вип. 1 (23) / Національний музей історії України у Другій світовій війні. Меморіальний комплекс, Ін-т історії України НАН України. - К., 2019. - С. 207-221. [Електронний ресурс]. — Режим доступу: https://vim. gov.ua/pages/_journal_files/23.05.2019/pdf/VIM_23_2019-207-221.pdf. — Назва з екрана.

4. Гейстінгс М. І розверзлося пекло... Світ у війні 1939-1945 років / М. Гейстінгс; пер. з англ. - Х.: Книжковий клуб «Клуб Сімейного Дозвілля», 2019. - 752 с.

5. Гриневич В. Політика пам’яті Другої світової війни в Україні: у пошуках ідентичності та консолідації / В. Гриневич // Наукові записки Ін-ту політ. і етнонац. досліджень ім. І.Ф. Кураса НАН України. — К., 2011. — № 4 (54). — С. 111-127.

6. Гриневич В. Український вимір війни та пам'яті про неї / В. Гриневич // Сучасні дискусії про Другу світову війну: Зб. наук. ст. та виступів українських і зарубіжних істориків. - Л.: ЗУКЦ, 2012. - С. 62-74.

7. Грицак Я. Незрозумілий Голокост / Я. Грицак // Сучасні дискусії про Другу світову війну: Зб. наук. ст. та виступів українських і зарубіжних істориків. — Л.: ЗУКЦ, 2012. — C. 86-98. 
8. Доманська Е. Історія та сучасна гуманітаристика: дослідження з теорії знання про минуле / Е. Доманська. - К.: Ніка-Центр, 2012. — 263 с.

9. Друга світова війна як виклик для української історіографії (Форум) // Україна модерна. — 2008. - Число 13 (2). — С. 13-60.

10. Сгрешій О.І. Й малорозбірливі рядки, й жива віра «між рядками» (Спроба «епістолярного» відтворення соціального портрета «малої людини») / О.І. Єгрешій // Війни пам'ятей та політика примирення: Зб. наук. праць. - К.: ДП «НВЦ «Пріоритети», 2013. - С. 20-27.

11. Скельчик С. Український досвід Другої світової війни / С. Скельчик. - К.: Медуза, 2020. $-272 \mathrm{c}$.

12. Калакура Я. Цивілізаційні орієнтири новітньої української історіографії / Я. Калакура // Історіографічні дослідження в Україні. Збірник наукових праць. - К., 2014. - Вип. 24. - С. 23-37.

13. Колесник I. Українська історіографія: концептуальна історія / І. Колесник. - К.: Ін-Т історії України НАН України, 2013. - 566 с.

14. Кондратюк К. Сучасна національна історіографія новітньої історії України (19142009 рр.): навч. посібн. / К. Кондратюк, О. Сухий. — Л.: Вид. центр ЛНУ імені Івана Франка, 2010. - $262 \mathrm{c}$.

15. Кузьменко А. Проблеми визначення ефективних методологічних підходів у музеєзнавстві / А. Кузьменко // Військово-історичний меридіан. Електронний науковий фаховий журнал. - Вип. 3 (9) / Національний музей історії України у Другій світовій війні. Меморіальний комплекс, Ін-т історії України НАН України. - К., 2015. - С. 134-139. [Електронний ресурс]. — Режим доступу: https:/vim.gov.ua/pages/_journal_files/08.10.2015/ pdf/VIM_9_2015_134-139.pdf. — Назва з екрана.

16. Легасова Л. Друга світова і Україна. Музейний аспект теми / Л. Легасова, Н. Шевченко// Сторінки воєнної історії України: зб. наук. ст. - К., 2008. - Вип. 11. - С. 20-31.

17. Лисенко О.С. Подолання «міфу війни», або від якої спадщини ми відмовляємося: науковий дискурс, політика пам'яті та сучасні виклики (з приводу 70-річчя перемоги над нацизмом і фашизмом) / О.С. Лисенко // Український історичний журнал. - 2015. — № 2. C. 4-21.

18. Лисенко О. Українська історіографія II світової війни: між закономірністю і парадоксом / О. Лисенко // Україна — Росія: діалог історіографій: Матеріали міжнар. наук. конф. - К. - Чернігів: РВК «Деснянська правда», 2007. - С. 143-156.

19. Маньковська Р. Тоталітаризм у суспільній пам'яті: музейні інтерпретації / Р. Маньковська // Україна ХХ століття: культура, ідеологія, політика: зб. ст. — К., 2017. — Вип. 22. - С. 112-127.

20. Нагорна Л.П. Історична культура: концепт, інформаційний ресурс, рефлексивний потенціал / Л.П. Нагорна. - К.: ІПіЕНД ім. І.Ф. Кураса НАН України, 2014. — 382 с.

21. Нагорна Л.П. Історична пам'ять: теорії, дискурси, рефлексії / Л.П. Нагорна. — К., ІПіЕНД ім. І.Ф. Кураса НАН України, 2012. - 328 с.

22. Нові підходи до історіописання / за ред. П. Берка; пер. $з$ англ. - К.: Ніка-Центр, 2010. - 368 c.

23. Нора П. Теперішнє, нація, пам’ять / П. Нора; пер. із фр. - К.: ТОВ «Видавництво «Кліо»», 2014. - 272 с. 
24. Пантьо Д. Музей Второй мировой войны в Гданське. История. Концепция. Нарратив / Д. Пантьо// Військово-історичний меридіан. Електронний науковий фаховий журнал. Вип. 3 (9) / Національний музей історії України у Другій світовій війні. Меморіальний комплекс, Ін-т історії України НАН України. - К., 2015. - С. 130-133. [Електронний ресурс]. Режим доступу: https://vim.gov.ua/pages/_journal_files/08.10.2015/pdf/VIM_9_2015_130-133. pdf. - Назва з екрана.

25. Патриляк І.К. Між двома проваллями: Україна в роки Другої світової війни / І.К. Патриляк // Проблеми всесвітньої історії. — 2016. — № 1. — С. 169-182.

26. Патриляк І.К. Україна в роки Другої світової війни: спроба нового концептуального погляду / І.К. Патриляк, М.А. Боровик. - Ніжин: ПП Лисенко М.М., 2010. — 590 с.

27. Пінгель Ф. Педагогічні виклики при написанні шкільного підручника з історії про Другу світову війну в Україні / Ф. Пінгель // Сучасні дискусії про Другу світову війну: Зб. наук. ст. та виступів українських і зарубіжних істориків. - Л.: ЗУКЦ, 2012. - С. 222-228.

28. Поль Д. Голокост, колаборація та спротив у Східній Європі / Д. Поль // Там само. C. $32-40$.

29. Портнов А. Історії для домашнього вжитку: Есеї про польсько-російсько-український трикутник пам’яті / А. Портнов. - К.: Критика, 2013. - 344 с.

30. Потапенко Я.О. Політичні маніпуляції навколо моделей пам'яті в сучасному українському соціокультурному дискурсі / Я.О. Потапенко // Війни пам’ятей та політика примирення: Зб. наук. праць. — К.: ДП «НВЦ «Пріоритети», 2013. - С. 82-94.

31. Потильчак О. Український вимір Другої світової: до дискусії про періодизацію вітчизняної історії війни / О. Потильчак // Історія в середніх і вищих навчальних закладах України. - 2005. - № 7. - С. 11-19.

32. Примаченко Я.Л. Війни пам'яті: історія ОУН і УПА в сучасному соціокультурному контексті українського історіописання / Я.Л. Примаченко // Проблеми історії України: факти, судження, пошуки: міжвід. зб. наук. пр. - К., 2013. - Вип. 22. - С. 18-30.

33. Снайдер Т. Чорна земля. Голокост як історія і застереження / Т. Снайдер, пер. з англ. Київ: Медуза, 2017. - 398 с.

34. Сошніков А.О. Актуальні проблеми сучасного розвитку музеїв України / А.О. Сошніков // Дев'яті Сумцовські читання. Матеріали наукової конференції «Музей і сучасність». - Х., 2004. - С. 4-7.

35. Стяжкіна О. Стигма окупації: Радянські жінки у самобаченні 1940-х років / О. Стяжкіна. - К.: ДУХ І ЛІТЕРА, 2019. - 384 с.

36. Сухий О. Сучасна історична наука в Україні: візії та напрями / О. Сухий // Україна Свропа - Світ. Міжнарод. зб. наук. праць. Серія: Історія, міжнародні відносини. Вип. 10. - Тернопіль: Вид-во ТНПУ ім. В. Гнатюка, 2012. - С. 22-36.

37. Топольський Є. Як ми пишемо і розуміємо історію. Таємниці історичної нарації / Є. Топольський. - К.: «К.І.С.», 2012. - 400 с.

38. Фоміна В. Деякі методичні засади створення та вдосконалення головної експозиції Меморіального комплексу / В. Фоміна // Військово-історичний меридіан. - Спецвипуск: 3 досвіду роботи Меморіального комплексу «Національний музей історії Великої Вітчизняної війни 1941-1945 років» / МКНМІВВВ; Ін-т історії України НАН України. - К., 2013. - С. 29-39. [Електронний ресурс]. — Режим доступу: https://vim.gov.ua/pages/_journal_files/07.10.2013/pdf/29-39.pdf. — Назва з екрана. 


\section{REFERENCES}

1. Boghdashyna O.M. Dzhereloznavstvo istoriji Ukrajiny: pytannja teoriji, metodyky, istoriji / O.M. Boghdashyna. — Kh.: Sagha, 2009. — 214 s.

2. Velyka L.P. Muzejne ekspozycijne mystectvo: monoghrafija / L.P. Velyka. — Kh.: KhDAK, 2000. - $160 \mathrm{~s}$.

3. Ghamarnyk N. Vystavky-aprobacijiv Nacionaljnomu muzeji istoriji Ukrajiny u Drughij svitovij vijni jak vyklyk majbutnij ekspozyciji / N. Ghamarnyk // Vijsjkovo-istorychnyj merydian. Elektronnyj naukovyj fakhovyj zhurnal. - Vyp. 1 (23) / Nacionaljnyj muzej istoriji Ukrajiny u Drughij svitovij vijni. Memorialjnyj kompleks, In-tistoriji Ukrajiny NAN Ukrajiny. - K., 2019. - S. 207-221. [Elektronnyj resurs]. — Rezhym dostupu: https://vim.gov.ua/pages/journal_files/23.05.2019/pdf/VIM_23_2019-207-221.pdf. — Nazva z ekrana.

4. Ghejstings M. I rozverzlosja peklo... Svit u vijni 1939-1945 rokiv / M. Ghejstings; per. z anghl. — Kh.: Knyzhkovyj klub «Klub Simejnogho Dozvillja», 2019. — 752 s.

5. Ghrynevych V. Polityka pam'jati Drughoji svitovoji vijny v Ukrajini: u poshukakh identychnosti ta konsolidaciji / V. Ghrynevych // Naukovizapysky In-tu polit. i etnonac. doslidzhenjim. I.F. Kurasa NAN Ukrajiny. — K., 2011. — № 4 (54). — S. 111-127.

6. Ghrynevych V. Ukrajinsjkyj vymir vijny ta pam'jati pro neji / V. Ghrynevych // Suchasnidyskusiji pro Drughu svitovuvijnu: Zb. nauk. st. ta vystupiv ukrajinsjkykh i zarubizhnyk historykiv. - L.: ZUKC, 2012. - S. 62-74.

7. Ghrycak Ja. Nezrozumilyj Gholokost / Ja. Ghrycak // Suchasni dyskusiji pro Drughu svitovu vijnu: Zb. nauk. st. ta vystupiv ukrajinsjkykh i zarubizhnyk historykiv. — L.: ZUKC, 2012. — S. 86-98.

8. Domansjka E. Istorija ta suchasna ghumanitarystyka: doslidzhennja z teoriji znannja pro mynule / E. Domansjka. - K.: Nika-Centr, 2012. - 263 s.

9. Drugha svitova vijnaja kvyklyk dlja ukrajinsjkoji istorioghrafiji (Forum) // Ukrajina moderna. - 2008. - Chyslo 13 (2). - S. 13-60.

10. Jeghreshij O.I. J malorozbirlyvi rjadky, j zhyvavira «mizh rjadkamy» (Sproba «epistoljarnogho» vidtvorennj asocialjnogho portreta «malojiljudyny») / O.I. Jeghreshij // Vijny pam“jatej ta polityka prymyrennja: Zb. nauk. pracj. - K.: DP «NVC «Priorytety», 2013. — S. 20-27.

11. Jekeljchyk S. Ukrajinsjkyj dosvid Drughoji svitovoji vijny / S. Jekeljchyk. - K.: Meduza, 2020. $-272 \mathrm{~s}$.

12. Kalakura Ja. Cyvilizacijni orijentyry novitnjoji ukrajinsjkoji istorioghrafiji / Ja. Kalakura // Istorioghrafichni doslidzhennja v Ukrajini. Zbirnyk naukovykh pracj. — K., 2014. — Vyp. 24. — S. 23-37.

13. Kolesnyk I. Ukrajinsjka istorioghrafija: konceptualjna istorija / I. Kolesnyk. - K.: In-t istoriji Ukrajiny NAN Ukrajiny, 2013. - 566 s.

14. Kondratjuk K. Suchasna nacionaljna istorioghrafija novitnjoji istoriji Ukrajiny (19142009 rr.): navch. posibn. / K. Kondratjuk, O. Sukhyj. - L.: Vyd. centr LNU imeni Ivana Franka, 2010. - $262 \mathrm{~s}$.

15. Kuzjmenko A. Problemy vyznachennja efektyvnykh metodologhichnykh pidkhodiv u muzejeznavstvi / A. Kuzjmenko // Vijsjkovo-istorychnyj merydian. Elektronnyj naukovyj fakhovyj zhurnal. — Vyp. 3 (9) / Nacionaljnyj muzej istoriji Ukrajiny u Drughij svitovij vijni. Memorialjnyj kompleks, In-t istoriji Ukrajiny NAN Ukrajiny. — K., 2015. — S. 134-139. [Elektronnyj resurs]. - 
Rezhym dostupu: https://vim.gov.ua/pages/_journal_files/08.10.2015/pdf/VIM_9_2015_134-139. pdf. - Nazvaz ekrana.

16. Leghasova L. Drugha svitova i Ukrajina. Muzejnyj aspekttemy / L. Leghasova, N. Shevchenko // Storinky vojennoji istoriji Ukrajiny: zb. nauk. st. — K., 2008. — Vyp. 11. — S. 20-31.

17. Lysenko O.Je. Podolannja «mifuvijny», abo vid jakoji spadshhyny my vidmovljajemosja: naukovyj dyskurs, polityka pam'jati ta suchasni vyklyky (z pryvodu 70-richchja peremogh y nadnacyzmom i fashyzmom) / O.Je. Lysenko // Ukrajinsjkyj istorychnyj zhurnal. — 2015. — № 2. - S. 4-21.

18. Lysenko O. Ukrajinsjka istorioghrafija II svitovoji vijny: mizh zakonomirnistju i paradoksom / O. Lysenko // Ukrajina - Rosija: dialogh istorioghrafij: Materialymizhnar. nauk. konf. — K. - Chernighiv: RVK «Desnjansjkap ravda», 2007. — S. 143-156.

19. Manjkovsjka R. Totalitaryzm u suspiljnij pam'jati: muzejni interpretaciji / R. Manjkovsjka// Ukrajina XX stolittja: kuljtura, ideologhija, polityka: zb. st. — K., 2017. — Vyp. 22. — S. 112-127.

20. Naghorna L.P. Istorychna kuljtura: koncept, informacijnyj resurs, refleksyvnyj potencial / L.P. Naghorna. - K.: IPiENDim. I.F. Kurasa NAN Ukrajiny, 2014. - 382 s.

21. Naghorna L.P. Istorychna pam'jatj: teoriji, dyskursy, refleksiji / L.P. Naghorna. - K., IPiENDim. I.F. Kurasa NAN Ukrajiny, 2012. - 328 s.

22. Novi pidkhodydo istoriopysannja / za red. P. Berka; per. z anghl. — K.: Nika-Centr, 2010. — $368 \mathrm{~s}$.

23. Nora P. Teperishnje, nacija, pam'jatj / P. Nora; per. izfr. — K.: TOV «Vydavnyctvo "Klio"», 2014. - $272 \mathrm{~s}$.

24. Panto D. Muzey Vtoroy mirovoy voyny v Gdanske. Istoriya. Kontseptsiya. Narrativ / D. Panto // Vijsjkovo-istorychnyj merydian. Elektronnyj naukovyj fakhovyj zhurnal. — Vyp. 3 (9) / Nacionaljnyj muzej istoriji Ukrajiny u Drughij svitovij vijni. Memorialjnyj kompleks, In-t istoriji Ukrajiny NAN Ukrajiny. - K., 2015. - S. 130-133. [Elektronnyj resurs]. — Rezhym dostupu: https://vim.gov.ua/ pages/_journal_files/08.10.2015/pdf/VIM_9_2015_130-133.pdf. — Nazva z ekrana.

25. Patryljak I.K. Mizh dvoma provalljamy: Ukrajina v roky Drughoji svitovoji vijny / I.K. Patryljak // Problemy vsesvitnjoji istoriji. — 2016. — № 1. - S. 169-182.

26. Patryljak I.K. Ukrajina v roky Drughoji svitovoji vijny: sproba novogho konceptualjnogho poghljadu / I.K. Patryljak, M.A. Borovyk. -Nizhyn: PP Lysenko M.M., 2010. — 590 s.

27. Pinghelj F. Pedaghoghichni vyklyky pry napysanni shkiljnogho pidruchnyka z istoriji pro Drughu svitovu vijnu v Ukrajini / F. Pinghelj // Suchasni dyskusiji pro Drughu svitovu vijnu: Zb. nauk. st. ta vystupi v ukrajinsjkykh i zarubizhnykh istorykiv. — L.: ZUKC, 2012. - S. 222-228.

28. Polj D. Gholokost, kolaboracija ta sprotyv u Skhidnij Jevropi / D. Polj // Tam samo. S. $32-40$.

29. Portnov A. Istoriji dlja domashnjogho vzhytku: Eseji pro poljsjko-rosijsjko-ukrajinsjkyj trykutnykpam'jati / A. Portnov. - K.: Krytyka, 2013. - 344 s.

30. Potapenko Ja.O. Politychni manipuljaciji navkolo modelej pam'jati v suchasnomu ukrajinsjkomu sociokuljturnomu dyskursi / Ja.O. Potapenko // Vijny pam'jatej ta polityka prymyrennja: Zb. nauk. pracj. — K.: DP «NVC «Priorytety», 2013. — S. 82-94.

31. Potyljchak O. Ukrajinsjkyj vymir Drughoji svitovoji: do dyskusiji pro periodyzaciju vitchyznjanoji istoriji vijny / O. Potyljchak // Istorija v serednikh i vyshhykh navchaljnykh zakladakh Ukrajiny. — 2005. — № 7. - S. 11-19. 
32. Prymachenko Ja.L. Vijny pam'jati: istorija OUN i UPA v suchasnomu sociokuljturnomu konteksti ukrajinsjkogho istoriopysannja / Ja.L. Prymachenko // Problemy istoriji Ukrajiny: fakty, sudzhennja, poshuky: mizhvid. zb. nauk. pr. — K., 2013. — Vyp. 22. - S. 18-30.

33. Snajder T. Chorna zemlja. Gholokost jak istorija i zasterezhennja / T. Snajder, per. z anghl. - Kyjiv: Meduza, 2017. - 398 s.

34. Soshnikov A.O. Aktualjni problem suchasnogho rozvytku muzejiv Ukrajiny / A.O. Soshnikov // Dev'jati Sumcovsjkichy tannja. Materialy naukovoji konferenciji «Muzej i suchasnistj». - Kh., 2004. - S. 4-7.

35. Stjazhkina O. Styghmaokupaciji: Radjansjkizhinky u samobachenni 1940-kh rokiv / O. Stjazhkina. - K.: DUKH I LITERA, 2019. - 384 s.

36. Sukhyj O. Suchasna istorychna nauka v Ukrajini: viziji ta naprjamy / O. Sukhyj // Ukrajina - Jevropa - Svit. Mizhnarod. zb. nauk. pracj. Serija: Istorija, mizhnarodni vidnosyny. - Vyp. 10. - Ternopilj: Vyd-vo TNPU im. V. Ghnatjuka, 2012. — S. 22-36.

37. Topoljsjkyj Je. Jak my pyshemo i rozumijemo istoriju. Tajemnyci istorychnoji naraciji / Je. Topoljsjkyj. — K.: «K.I.S.», 2012. - 400 s.

38. Fomina V. Dejaki metodychni zasady stvorennja ta vdoskonalennja gholovnoji ekspozyciji Memorialjnogho kompleksu / V. Fomina // Vijsjkovo-istorychnyj merydian. — Specvypusk: Z dosvidu roboty Memorialjnogho kompleksu «Nacionaljnyj muzej istoriji Velykoji Vitchyznjanoji vijny 1941-1945 rokiv» / MKNMIVVV; In-t istoriji Ukrajiny NAN Ukrajiny. — K., 2013. — S. 29-39. [Elektronnyj resurs]. — Rezhym dostupu: https:/vim.gov.ua/pages/_journal_files/07.10.2013/ pdf/29-39.pdf. — Nazva z ekrana.

Legasova L.V., Honored Worker of Culture of Ukraine, Deputy Director General for Research of the National Museum of the History of Ukraine in the Second World War. Memorial Complex (Kyiv, Ukraine) ORCID https://orcid.org/0000-0002-4312-4914

Simperovych V.M. , Candidate

of Historical Sciences, Scientific Secretary of the National Museum of the History of Ukraine in the Second World War. Memorial Complex (Kyiv, Ukraine) ORCID https://orcid.org/0000-0001-7845-0667

\section{EXHIBITION MODEL OF THE HISTORY OF THE SECOND WORLD WAR IN UKRAINE: CONCEPTUALIZATION, NARRATION, REPRESENTATION (from the experience of the National Museum of the History of Ukraine in the Second World War. Memorial Complex)}

An urgent task for each museum institution is to bring the exhibition space in line with modern challenges. Based on the conceptual schemes, the research and exposition practices produced by the National Museum 
of the History of Ukraine in the Second World War, the article aims to show what should be / become an expositional model of the Ukrainian vector of the largest military conflict of the twenti eth century.

The sustainable concept of the expositional model of the history of the war depends exclusively on the peculiarities of the historiographical situation, the theoretical postulates of scientists and the level of effective implementation of these works in museum practice. The modern conceptual model of Ukraine's history in the Second World War is based on a kind of "interweaving / mixing" of the components of the "old" (modified and deconstructed Soviet) and "new" (national) historiographical discourses. The answer to this should be a balanced, "comparative" approach, which should synthesize these two historiographical versions of the Ukrainian dimension of the Second World War. Creating its own theoretical vision, the Museum (after all, like any other museum institution that exhibits a particular theme of the past war) should be a combination of different elements of reproduction of narratives of different worldviews, allowing comparison of different approaches to wartime history. The expositional formation of the history of Ukraine in the Second World War should take into account first of all the anthropological and then the eventual dimensions of the war era. The exhibition space should "immerse" in the atmosphere of wartime, to transfer its internal tension and existentialism.

The proposed conceptual and narrative-representational approaches to the interpretation of the Ukrainian dimension of the Second World War can serve as a convincing example and be used as an effective option for potential museum-exhibition transformations.

Keywords: World War II, Ukrainian dimension of the Second World War, National Museum of the History of Ukraine in the Second World War. Memorial Complex, exposition model, conceptualization, museum narration, museum representation. 